\title{
Geologiske kort i Danmark - hvad viser de kvartcergeologiske kort
}

Af Peter Gravesen, Stig A. Schack Pedersen, Knud Erik S. Klint og Peter Roll Jakobsen, alle fra Danmarks og Grønlands Geologiske Undersøgelse (GEUS)

Denne artikel er et svar på foregående debatindlæg om "det ærlige jordartskort", hvori forfatterne forklarer bagrunden for fremstillingen af geologiske kort i Danmark.

\section{Hvorfor geologiske kort?}

Alle lande i Europa og Nordamerika samt mange af verdens øvrige lande har en Geologisk Undersøgelse, hvis opgave det er at kortlægge landets geologiske forhold. Danmarks og Grønlands Geologiske Undersøgelse (GEUS) varetager denne opgave i både Danmark og Grønland samt de danske territorialfarvande. Den væsentligste årsag til, at der udføres geologisk kortlægning, er, at der i alle lande er behov for at have et overblik over de naturlige, fysiske forhold, som er baggrund for samfundets planlægning og forvaltning af efterforskning, beskyttelse og udnyttelse af naturressourcerne. Et geologisk kort er særdeles velegnet til disse opgaver. Kortlægningen foregår på baggrund af videnskabelige metoder, og den drager nytte af alle de forskningsresultater, som geologerne i Danmark offentliggør. På samme måde bidrager kortlægningen til den geologiske videnskab ved blandt andet at sammenstille geologiske data på regional skala, og dermed medvirker den til, at Danmarks geologiske forhold kan opfattes og ses i en større sammenhæng, der rækker ud over en råstofgrav eller en kystklint.

GEUS kortlægger mange forskellige geologiske temaer, men dette indlæg vil kun fokusere på kortlægningen af Danmarks overfladenære lag, som især består af kvartære aflejringer fra de sidste 200.000 år, men som stedvis i landet også består af ældre sedimenter og bjergarter.

\section{Fremstilling af kort over DK i 1:50.000} Siden 1980 har Kort \& Matrikelstyrelsens inddeling i kortblade i 1.50 .000 været rammen for fremstilling af Geologisk kort over Danmark (se figuren til højre). Kortlægningen foretages systematisk, men efter en prioriteret plan, som afspejler behovet for kortene. De geologiske kort viser et billede af den naturlige landskabsopbygning i tre

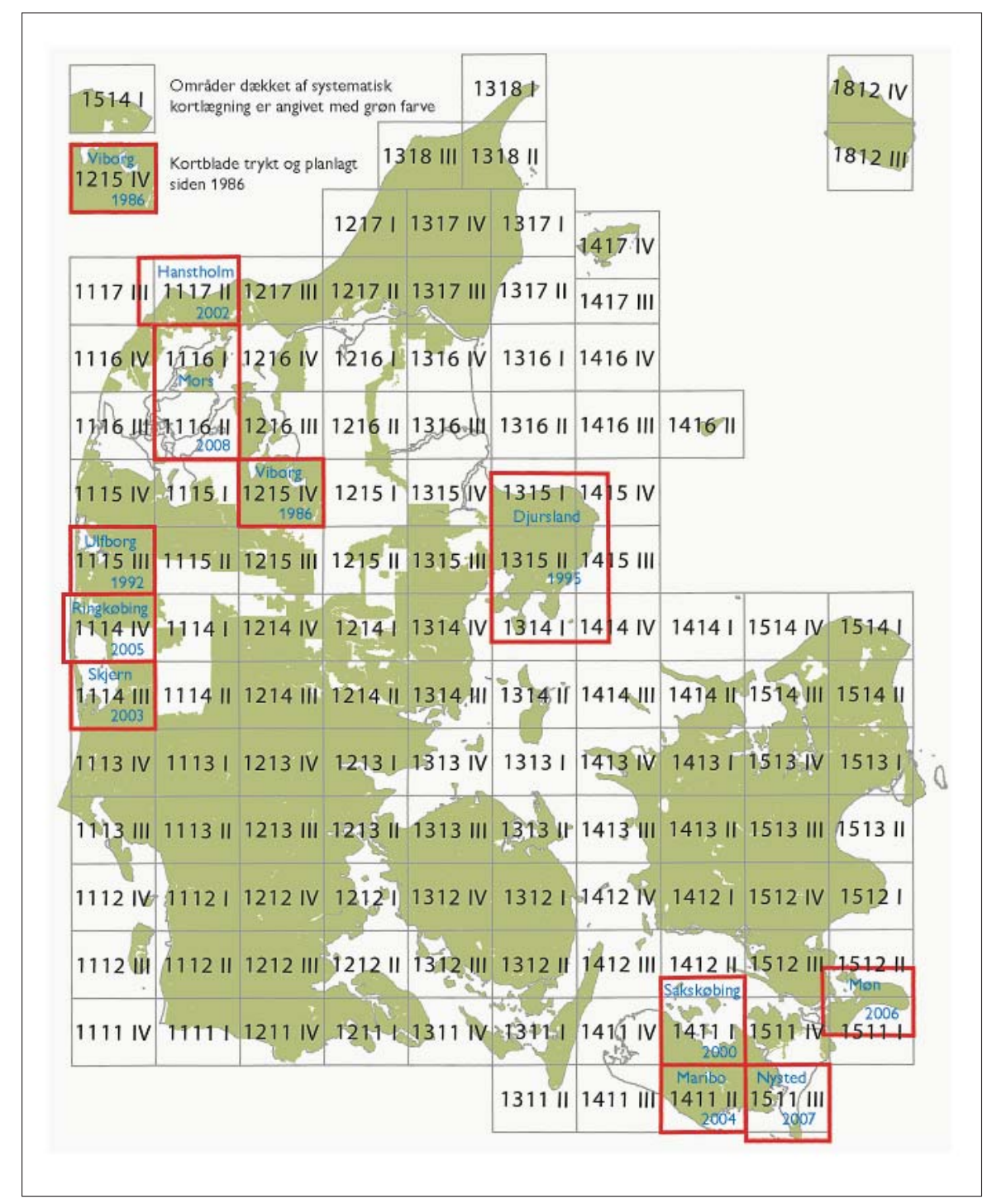

Kortbladsinddeling i serien “Geologisk Kort over Danmark 1:50.000”. De seneste års udgivelser er markeret, ligesom de næeste planlagte kort er vist. (Grafik: Benny Schark, GEUS)

dimensioner, som er omsat til plane kort. Den væsentligste proces til at fremstille dette billede er feltarbejdet, hvor kortlægningen eller karteringen foretages. Det er kun ved feltarbejdet, at landskabet kan aflæses, og hvor forekomsten af jordarter, sedimenter og bjergarter umiddelbart kan sammenholdes med landskabets højder og lavninger, så processer og udvikling kan bedømmes og tolkes.

GEUS-geologer kortlægger landskabets sedimenter, processer og landskab ved hjælp af et jordspyd, som bores ned til 1 meters dybde med 100 til 200 meters mellemrum, men antal af sonderinger og hyppigheden af dem afpasses i øvrigt efter den geologiske situation. Sonderingerne med jordspyddet foretages dels for at fastlægge grænsen mellem to forskellige jordarter og dels for at dokumentere, at hver kortlagt polygon er identificeret. Karteringsmæssigt er overfladen defineret som en meter under overfladen bl.a. for at undgå konflikt med klassifikation af jordbundstyper, men det er også den dybde, et jordspyd kan nå ned til. Det opborede sediment bedømmes med hensyn til 
sammensætning, dannelse og alder.

Sedimentoplysningerne indtegnes på

Kort \& Matrikelstyrelsens topografiske kort i 1:25.000 med kortlægningssymboler, og $i$ felten foretages desuden en indtegning af grænselinier mellem forskellige sedimenttyper. Sedimenttyperne og grænselinierne vurderes sammen med de geomorfologiske forhold i området. På samme måde indsamles og inddrages informationer om de sedimentære facies og om glacialtektoniske forhold m.m. fra råstofgrave, udgravninger og kystklinter samt fra dybere boringer. Informationer om boringerne findes i GEUS's borearkiv, Jupiter boringsdatabasen og på de Geologiske Basisdatakort, som blev fremstillet ved den landsdækkende hydrogeologiske kortlægning. Der indsamles også prøver, som analyseres i GEUS laboratorier for sedimenternes kornstørrelsessammensætning og petrografiske egenskaber m.m. (fingrus, ledeblokke, humus, kalkindhold, mikrofossiler).

Det er således et omfattende materiale, der indgår ved den geologiske kortlægning, og som bidrager til, at slutproduktet bliver så godt som muligt.

\section{Kortenes indhold}

I kortlægningen af Danmarks overfladenære aflejringer er differentieret omkring 50 forskellige kvartære enheder, som forsøges identificeret ved feltarbejdet. De kvartære jordarter er på de geologiske kort trykt med farvesymboler, hvorimod de prækvartære jordarter er angivet med et bogstavsymbol eller farvesymbol. Symbolerne angiver samlet jordarternes sammensætning, dannelse og alder. De kvartære aflejringer kan opdeles i tre store grupper: de glaciale aflejringer, de senglaciale aflejringer og de postglaciale aflejringer. De postglaciale aflejringer svarer til sedimenter aflejret i Holocæn tid, altså recente og subrecente aflejringer fra de sidste 11.700 år. De senglaciale aflejringer benævnes også flodsletteaflejringer og er aflejret i områder uden for isranden i Sen Weichsel tid (fra ca. 25.000 til 11.700 år siden). En konsekvens heraf er, at disse aflejringer aldrig blev overskredet af en gletscher eller iskappe, og de udgør de markante hedesletter (fx Karup og Tirstrup Hedesletter), samt issøaflejringer, og de glaciomarine aflejringer i Vendsyssel. De glaciale aflejringer består af smeltevandsler, -sand og -grus samt moræneaflejringer.

De glaciale aflejringer har alle på et tidspunkt under istiden været dækket af en gletscher. Moræneaflejringerne kan dels være moræneler eller morænesand. I visse områder består moræneaflejringerne af mere end $50 \%$ kalk oparbejdet og omlejret fra den lokale prækvartære undergrund. Denne type jordart er på Djursland angivet som kalkmoræne (kalkmorænesand eller kalkmoræneler). I israndsstrøg optræder stedvis morænegrus, som mest har karakter af et grovklastisk iskontaktsediment. Men fælles for alle de glaciale aflejringer er, at de har været belastet af vægten fra et isdække. Moræneler og morænesand er på de geologiske kort angivet med hver sin brune farve (olivenbrun for moræneler og rødbrun for morænesand). Den erfarne geolog kan let ud fra jordartens sortering bedømme, om det er en moræneaflejring eller smeltevandsaflejring.

\section{Hedeslettter og ekstramarginalt sand}

De store og udbredte hedesletteaflejringer, som ofte kaldes ekstramarginale aflejringer, har derimod ikke været påvirket af iskapper. De sedimentære facies for flodslettesand og andre smeltevandssandaflejringer kan godt være ens, men opmåling, beskrivelse og tolkning af sand-grusaflejringernes horisontale og vertikale opbygning vil henføre dem til forskellige aflejringsmiljøer som floder, søer, deltaer og hedesletter. De klimatiske, fysiske og biologiske vilkår efter aflejringen medfører, at jordarterne også godt kan være forskellige. Det giver sig bl.a. udslag $i$, at hedesletternes sandaflejringer er stærkt præget af vindens påvirkninger med vindslebne sand, grus og sten, og at de har et meget kraftigere udviklet podsol-profil end tilsvarende smeltevandssand under morænedækket.

Udvaskningen af kalk er også større for 
de ekstramarginale aflejringer. Så sammenholdt med de geomorfologiske karakteristika er der al mulig grund til, at der er skelnet mellem ekstramarginalt flodsand og glacialt smeltevandssand med forskellig farve på GEUS's jordartskort. Benævnelserne er desuden en del af vores historiske arv, ligesom diluviale aflejringer i sin tid blev gjort identiske med istidsaflejringer. Vigtigst er det dog, at det er klargjort i legenden, hvad de enkelte enheder står for, og at denne forklaring retfærdiggør anvendelsen af henholdsvis en rød og en orangegul farve på kortet.

\section{De kvartære aflejringers udbredelse}

De kvartære aflejringers sammensætning og udbredelse på landsplan kan vurderes ud fra de Geologiske Basisdatakort og jordartskortene, især hvis der er tale om hele den kvartære lagsøjle fra jordoverfladen til prækvartæroverfladen (tykkelser fra under 1 meter til 100-300 meter). Boringerne repræsenterer lodrette profiler gennem alle de kvartære tidsafsnit, der kendes i Danmark. Boringer indgår således som basis for konstruktionen af de geologiske tværprofiler/ blokdiagrammer på jordartskortene. Forholdet mellem moræneaflejringer på den ene side og smeltevandsaflejringer på den anden side veksler fra istid til istid, men almindeligvis er jordartstyperne de samme. Der er god overensstemmelse mellem moræneaflejringerne på jordartskortene og tilstedeværelsen i toppen af boringerne, men inden for de dybereliggende lag kan fordelingen være en anden. Denne er ikke opgjort, bl.a. fordi dette er vanskeligt at gøre, da der, på trods af at der findes ca. 300.000 boringer i GEUS's Borerakiv, kun er ca. 8 boringer pr. $\mathrm{km}^{2}$, og boringerne desuden er uregelmæssigt fordelt.

Inden for overfladelagene, som overvejende består af aflejringer fra Weichsel og Saale, er fordelingen for hele Danmark opgjort til at være ca. $40 \%$ moræneler, ca. $3 \%$ morænesand, ca. $28 \%$ smeltevandssand og grus og ca.1-2\% smeltevandsler, mens de sidste ca. $27 \%$ udgøres af de holocæne og prækvartære aflejringer.

Det er muligt, at den samlede mængde af glaciale aflejringer i Danmark overvejende består af smeltevandssand, men dette bør dog ikke misforstås derhen, at den brune farve på GEUS's jordartskort ikke til fulde og hele dækker udbredelsen af de overfladenære moræneaflejringer.

\section{Det trykte geologiske kortblad}

Det endelige geologiske kort redigeres sammen i de geologiske kortblade, som Geologisk Kort over Danmark, og trykkes i målestoksforhold 1:50.000 (figuren til højre). Dette kort er resultatet af en sammenstilling af alle de data, som er indsamlet i felten, arkiverne og laboratorierne. Denne sammenstilling er en tolkning af de geologiske forhold inden for det kortlagte område, og derfor er alle de viste geologiske enheder
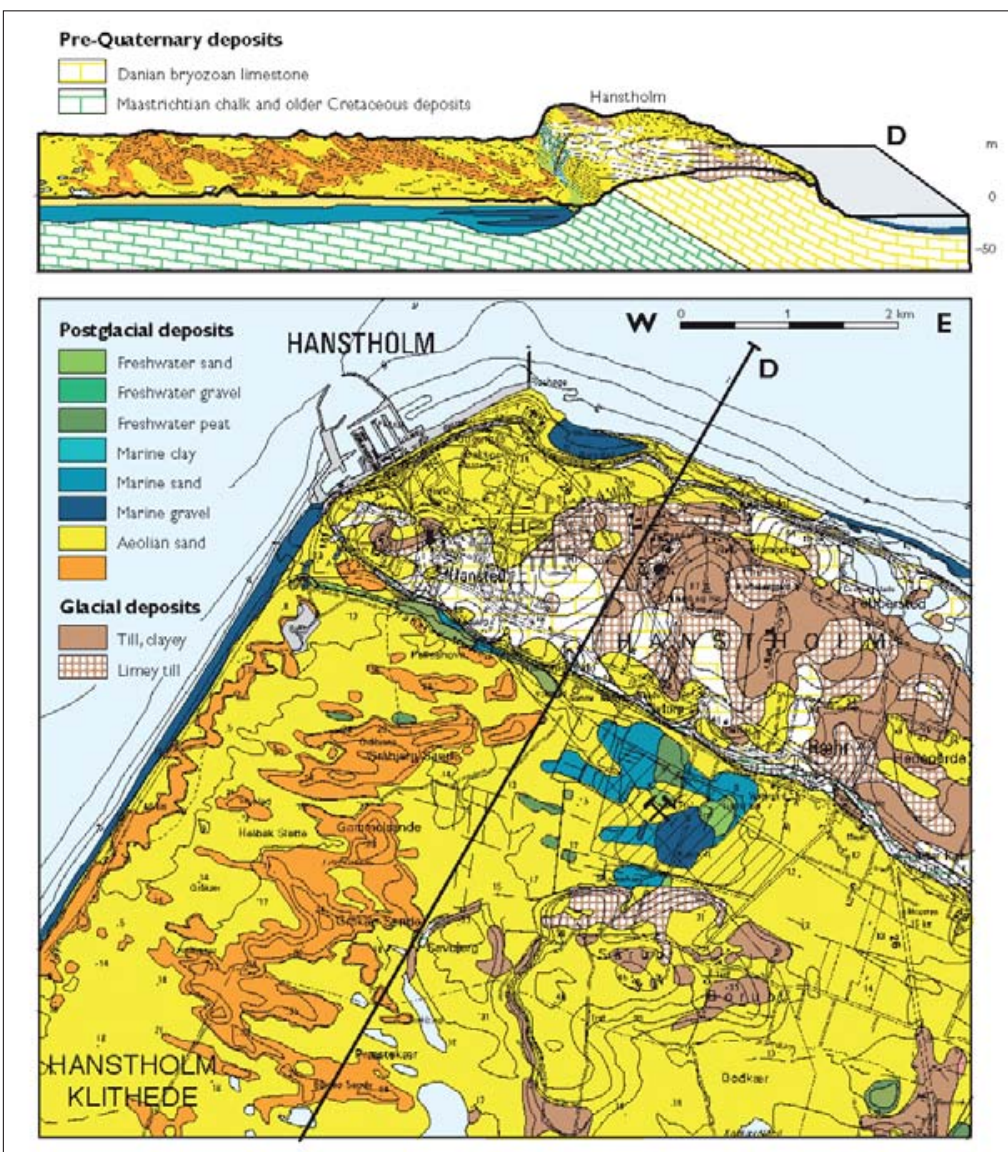

Kortbladsudsnit med tilhørende tvæerprofil-blokdiagram fra Hanstholm Kortbladet. (Grafik: Benny Schark, GEUS)

som følge deraf vist i overensstemmelse med sammensætning, dannelse og alder. På det trykte kort ses også repræsentative geologiske tværprofiler og/eller blokdiagrammer, som viser de kvartære lags opbygning og de dybereliggende aflejringer (figuren ovenfor). Der findes også vignet/temakort i marginen, som giver oversigt over prækvartæroverfladens højdeforhold, såvel som kort over områdets geomorfologiske hovedelementer. Under kortbladet er den geologiske opbygning desuden beskrevet i en kortfattet tekst.

\section{Det digitale kort}

De kvartærgeologiske kort, som er fremstillet af GEUS, er løbende blevet digitaliseret og ligger nu i en GIS-database, således at oplysningerne kan bruges sammen med andre data. Inden for de sidste 15 år er digitaliseringen foretaget på originale feltkort, som medtager detaljer, der er læsbare på feltkort i målestok 1:25.000. Disse kort blev tidligere benævnt de Foreløbige Jordartskort. Ud over at ligge i GEUS's database, kan kortene også rekvireres på en CD-rom.

Kort over Danmarks Jordarter i 1:200.000 I 1989 udgav GEUS (DGU) et kvartærgeologisk kort, der blev navngivet Danmarks Jordarter i målestoksforhold 1:200.000, som foreligger i fire delkort og på en CD-rom (figuren på næste side). Kortet blev udarbejdet på grundlag af den foreliggende kortlægning i 1:25.000 og alle andre informationer, der var til rådighed, men feltarbejde indgik ikke i arbejdet. Omarbejdelsen fra 1:25.000 til 1:200.000 indebærer en forenkling af det geologiske tema, hvorfor der er langt færre informationer på kortet. Desuden blev områder, der ikke på daværende tidspunkt var karteret, kortlagt ved hjælp af alle de andre eksisterende data. Det er derfor et oversigtskort, men det er selvfølgelig baseret på det grundige arbejde, som ligger til grund for de oprindelige kort, som er beskrevet ovenfor.

Det er vigtigt at gøre sig klart, at et kort er redigeret $\mathrm{i}$ forhold til den målestok, det skal læses i. Det kan derfor ikke forlanges, at detaljeringsgraden automatisk kan leve op til en forstørrelse eller nedsætning af det givne kortværk. Kortet er navngivet: "Danmarks Jordarter", men det er et tolket geologisk kort, helt på linje med de grundlæggende kort.

\section{Kortets indhold}

Da der er tale om et forenklet geologiske kort, må de temaer som findes på kortet også være forenklede. Signaturforklaringen viser indholdet, som er delt op i 11 forskellige enheder, hvoraf 5 viser holocæne aflejringer, 2 moræneaflejringer, 3 smeltevandsog ekstramarginale aflejringer og 1 ældre havaflejringer

Ved anvendelsen er det vigtigt at holde 
databaggrund og målestok for øje, men overvejelserne angående sedimentsammensætning, dannelse og alder for dette kort er de samme som for kortene i 1:50.000.

\section{Supplende kort}

De kvartærgeologiske kort i henholdsvis 1:50.000 og 1:200.000, som viser de geologiske forhold i 1 meters dybde, kan suppleres med en række andre datatyper, som både kan komplettere og supplere de geologiske data. Der kan peges på jordbundskort fra bl.a. Danmarks Jordbundsforskning (DJF), som især viser de øverste $\mathrm{cm}$ af jordlagene. Flyfotos kan anvendes ved analyse af forholdene, og i dag kan fremstilles instruktive højdemodeller, der enten som reliefkort eller som 3-D blokdiagrammer kan indgå $\mathrm{i}$ tolkningen af terrænformerne. Overfladegeofysik er i de senere år indsamlet i store mængder $i$ amterne, og disse data samles $i$ GEUS's Gerda-database, ligesom nye metoder kan bidrage væsentligt ved dataindsamling inden for de øverste meter.

Disse metoder kan dog ikke erstatte den geologiske dataindsamling og tolkning af jordlag og landskab, men kan med stor fordel anvendes sammen med kortlægningen.

\section{Kritik af de geologiske kort}

I Geologisk Nyt nr. 1 fra 2004 fremførte Ib Marcussen vedrørende forekomsten af sand at "når man på GEUS's jordartskort angiver to forskellige farver, er det i virkeligheden misvisende, for der er ikke forskel på selve sedimentet på de to sider af Ussings linie", og Troels Østergaard fremfører i Varv nr. 3, 2005 samt i dette nummer i artiklen før en lignende tanke, idet han ved skrivebordet overfarver GEUS jordartskort i 1:200.000 og skriver: "Jamen, et jordartskort er - bør være - et lithologisk kort", som argument at for samme type sand (med rødt) findes over større områder i Jylland. Vi må tilbagevise de to forfatteres anker mod indholdet af GEUS's geologiske kort. Ankerne må enten skyldes ukendskab til kortenes indhold og fremstilling, eller udelukkende være forfatternes forsøg på at tjene egne interesser $\mathrm{i}$ forhold til diskussioner af den danske landskabs dannelse.

En idé om kun at kortlægge sedimenttyper: grus, sand, silt, ler uden nogen form for geologisk tolkning er uden mening, og et sådant kort er uanvendeligt $\mathrm{i}$ en hver form til de opgaver, hvor der anvendes geologiske kort til løsningen af samfundets behov inden for arealforvaltning, hvor alle relevante oplysninger skal bruges. Det “ærlige jordartskort" må derfor afvises. De kort, som ikke er geologisk tolkede, kan kun anvendes i snævre sammenhænge, og det er ikke formålet med en geologisk kortlægning.

Troels Østergaard kritiserer GEUS's jordartskort fra 1989 for at være skyld i (har vildført) danskernes opfattelse af Hovedopholdslinjen i det danske landskab. Det virker noget besynderligt, da kortet er fra 1989, og

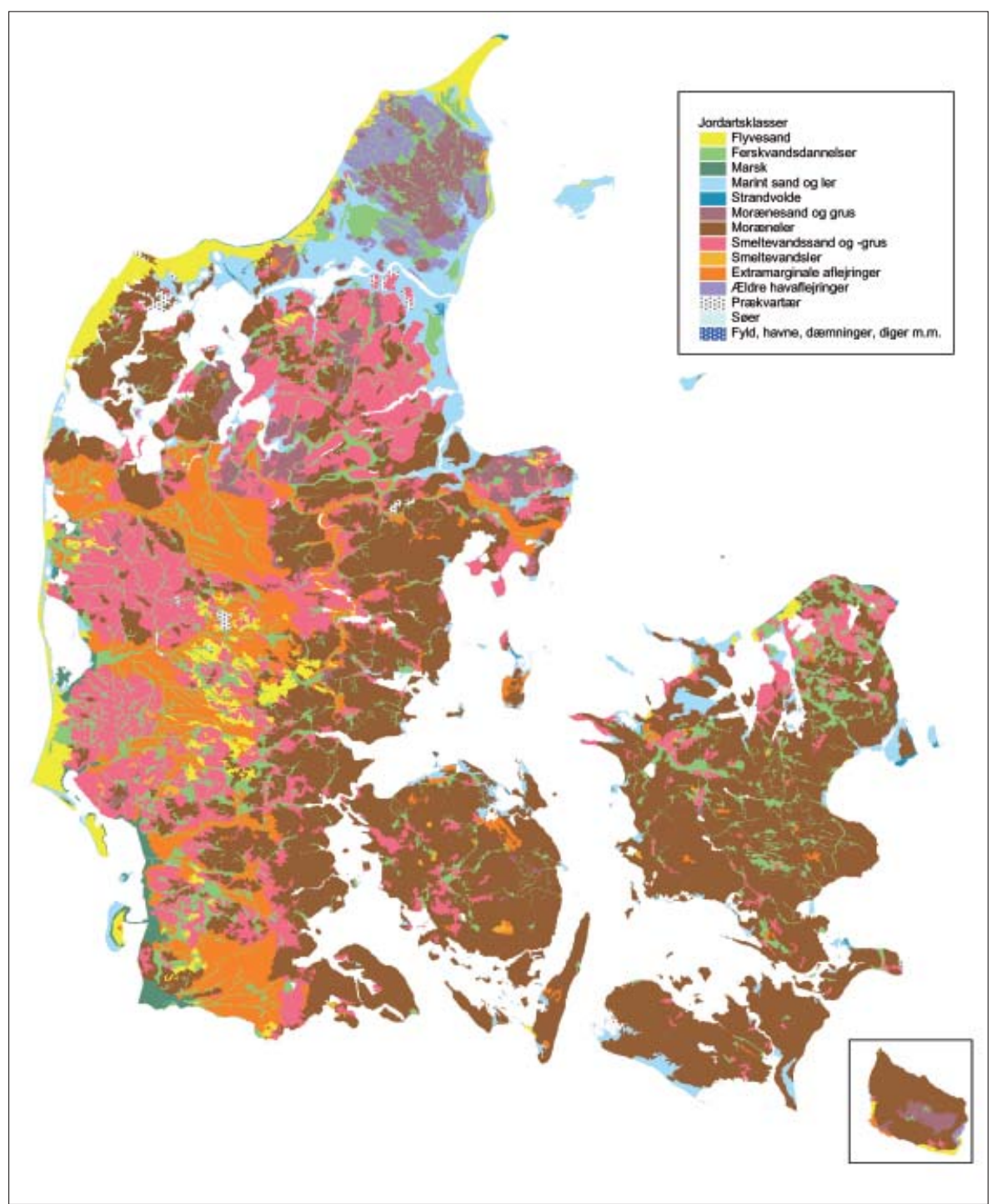

Kort over Danmarks Jordarter i målestok 1:200.000, men her i reduceret størrelse. (Grafik: Bjørn Hermansen, GEUS)

tanken om Hovedopholdslinjen er tilbage fra Ussing i 1903, og da der i øvrigt intet står om Hovedopholdslinjen på kortet.

Det skal samtidig stærkt beklages, at Troels Østergaard i VARV prøver at inddrage en personlig samtale med en nu afdød DGU-medarbejder, en samtale der må være ført for over 20-30 år siden, og det for at give indtryk af de geologiske korts manglende troværdighed og for at forfølge sine egne snævre formål. Det er utroværdigt og uværdigt.

\section{Kortenes anvendelse}

De geologiske kort anvendes i en række vigtige sammenhænge som en del af planlægningsgrundlaget ved arealforvaltningen i det åbne land almindeligvis sammen med en række andre kort omhandlende især de fysiske og biologiske forhold m.v.. Kortene bruges i forbindelse med grundvandsbeskyttelse og planlægning, fx ved kortlægning af "Områder med Særlige Drikkevandsinteresser" for amterne, råstofefterforskning for amter og private firmaer, landbrugsplan- lægning, skovplanlægning, planlægning af vådområder, fredningsplanlægning og habitatsområder for statslige styrelser, anlægsprospektering til veje, broer, tunneler og bygninger for kommuner, amter, private firmaer og staten, opgaver i forbindelse af de danske National Parker samt som bidrag til den kvartærgeologiske, videnskabelige udvikling.

\section{De seneste års produktion og fremtiden} Inden for de seneste 20 år kan GEUS-produktion af geologiske kort siges at være delt op i to perioder: Mellem 1986 og 1995 blev udgivet tre kort: Viborg, 1986, Ulfborg, 1992 og Djursland, 1995. Efter en pause er der de seneste fem år sket en intensivering af kortlægningen med udgivelse af kortene Sakskøbing, 2000, Hanstholm, 2002, Skjern, 2003, Maribo, 2004 og Ringkøbing, 2005. I 2006 afsluttes og udgives Møn-kortbladet.

Planen for fremtiden er, at der de kommende år arbejdes på udgivelse af et kort pr. år startende med kortblade, som dækker 
den østlige del af Lolland og sydlige del af Falster: Nysted, den nordlige del af Falster og områderne omkring Mors.

Udover den systematiske kortlægning på Ringkøbing-kortbladet og på Lolland-Falster i 2004 og 2005 kortlagde GEUS i 2004 på Østmøn i forbindelse med arbejdet omkring den mulige National Park og i 2005 i Rold skov til brug for skovplanlægning.

\section{Afslutning}

GEUS's opgaver fordrer stadig målrettet kvartærgeologisk kortlægning for at løse de opgaver, som til stadighed skal varetages. Det er GEUS's mål at forsætte en systematisk kortlægning af Danmark, men også at løse de ad hoc kortlægningsopgaver, som til stadighed dukker op. GEUS vil også fortsætte med at udvikle kortlægningsmetoder og især designet af de geologiske kort i 1:50.000, en udvikling som har været løbende i gang de seneste år. GEUS's kvartærgeologiske kort vil fortsat være geologisk tolkede kort, som kan anvendes i så mange samfundsorienterede opgaver som muligt.

\section{Litteratur}

Gravesen, P., 1993: Geologisk basisdatakort, 1:50.000, Kortbladet 1115 III Ulfborg, Danmarks Geologiske Undersøgelse, Kortserie nr. 25.

Jakobsen, P.R., Pedersen, S.A.S. \& Pe- tersen, K.S., 2003: Geologisk kort over Danmark, 1:50.000, Skjern. Danmarks og Grønlands Geologiske Undersøgelse.

Pedersen, S.A.S (kompl.), 1989: Danmarks Jordarter i 1.200.000. Fire kortblade. Danmarks Geologiske Undersøgelse.

Pedersen, S.A.S. \& Petersen, K.S., 1997: Djurslands Geologi. Danmarks og Grønlands Geologiske Undersøgelse, 96 sider + Geologisk kort over Djursland.

Pedersen, S.A.S. \& Petersen, K.S., 2002: Geologisk Kort over Danmark, 1:50.000, Hanstholm. Danmarks og Grønlands Geologiske Undersøgelse.

\section{Kort nyt}

\section{Mårup Kirke ikke lcengere fredet}

Onsdag d. 15. marts 2006 ophævede kulturministeren fredningen af Mårup Kirke ved Lønstrup og har derved stadfæstet Kulturarvsstyrelsens afgørelse, selvom kulturministeren inden har behandlet en anke fra et lokalt ægtepar og foreningen "Mårup Kirkes Venner".

Det er ikke noget nyt, at kirken er på afgrundens rand. På grund af kystnedbrydningen har man længe vidst, at kirken ville styrte i havet engang. Det er tankevækkende, at for blot 200 år siden lå kirken omkring en halv kilometer inde i landet. Skov- og Naturstyrelsen har udarbejdet en plan for, hvad man skal gøre, når kirken er 15 meter fra skrænten. Taget skal tages af og murene nedbrydes til en vis højde af sikkerhedsmæssige hensyn. Man skal stadig kunne bevæge sig sikkert rundt om kirken. 15 metersgrænsen forventes nået efter vinterens storme.

Planen har dog ikke kunnet iværksættes før ophævelsen af fredningen, da dele af kirken (kirkens nordside samt det meste af koret) var fredet grundet dens høje alder - kirken er fra før 1536. Ifølge $\S 4$, stk. 1 i lov om bygningsfredning af bevaring af bygninger og bymiljøer er bygninger opført før dette årstal fredede. Kirken er opført $i$ 1200 -tallet i senromansk stil af store strandsten og teglsten. Det store anker på vestsi-

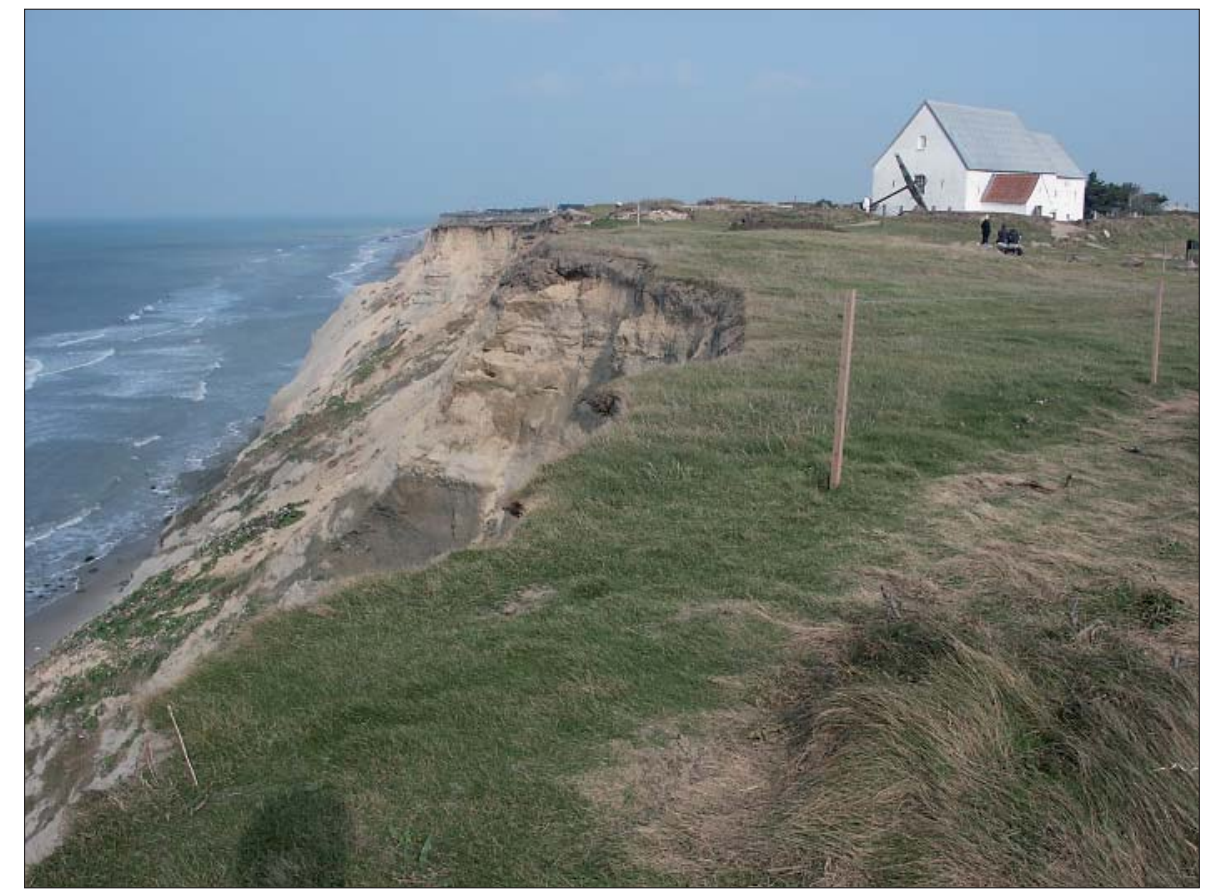

Mårup Kirkes udsatte beliggenhed ved skrcenten. (Foto: Morten L. Hjuler)

den stammer fra forliset af en engelsk fregat uden for kysten i 1808 .

Grunden til, at sagen ikke hører under Kirkeministeriet, er, at der ikke længere afholdes gudstjenester i folkekirke-regi (den dengang nye Lønstrup Kirke overtog tjenesterne i 1928) - fredningsspørgsmålet er en sag for Kulturarvsstyrelsen, og de har altså nu ophævet fredningen.

Kuas.dk/UVH 